\title{
Merkeziyetçilik Anlayışının Yerel Düzeyde Siyasal Katılıma Etkileri Üzerine Kavramsal Bir Değerlendirme
}

Konur Alp Demir ${ }^{1}$

Merkeziyetçilik Anlayışının Yerel Düzeyde Siyasal Katılıma Etkileri Üzerine Kavramsal Bir Değerlendirme

\section{Öz}

Merkeziyetçilik üniter yapıya sahip ve geleneklerine bağlı devletlerin uygulamalarına yansıttıkları bir ilkedir. Bu tür uygulamalar devletin işleyiş yapısında bir takım aksaklıklara sebebiyet verebilmekte, vatandaşı aktif katılımcı olmaktan uzaklaştırarak pasif birer kabullenici konumuna geriletmektedir. Uzun dönemler boyunca tartışılan ve çareler aranan merkeziyetçilik uygulamalarına üretilen çözümler genel anlamda yerelleşme ekseni etrafında toplanmaktadır. Bu çalışmada ise yerelleşme kavramına vurgu yapılarak sivil toplumu ana kurgu etrafında yeniden şekillendirmek temel esas olarak benimsenmiştir. Bu amaç doğrultusunda öneriler geliştirilmiş ve bir takım kavramların gündeme gelebilmesi için bir tartışma ortamı yaratılmaya çalışılmıştır.

Anahtar Kelimeler: Merkeziyetçilik, Yerelleşme, Sivil Toplum, Sivil Katılım, Sinerji.
A Conceptual Evaluation and Recommendations on the Effects of Centralization's Understanding of Local Levels on Political Participation

Abstract

Centralization which is got off the ground by the states which are loyal to their traditions and have unitary structure is a principle. Such practices may cause some disruptions in the way that the state operates and they are moved the citizens away from being an active participant to passive ones in accepting position. The solutions to centralized practices, which have been discussed and remedied over a long period of time, generally converge around localization. In this study, it is basically adopted to reshape civil society around the main idea by emphasizing the concept of localization. Suggestions have been developed in line with this aim and an attempt has been made to create a discussion environment for a number of concepts to come to an end.

Keywords: Centralization, Decentralization, Civil Society, Civil Participation, Synergy.

\section{Giriş}

Türk yönetim gelenekleri ve Türk toplumu tarihsel açıdan incelendiği takdirde devlet yapılanmasına önem verildiği görülecektir. Bu önemin sınırları devleti kutsallaştırmaya kadar genişlemektedir. Tanrı'nın yeryüzündeki gölgesi veya temsilcisi devlet yapılanması ile simgelenmeye çalışılmıştır (Çaha, 2012: 9).

Devletin motor gücünü oluşturan kamu yönetimi sistemi "klasik sömürgecilik..." anlayışından evrimleşerek "çağdaş sömürgeci..."lik anlayışı kapsamında yeniden kurgulanmıştır. İki aşama arasında geçiş yapılırken kamu yönetimi mantığı şekillenmiş ve bu mantık genel hatları ile yönetim, evrak takipçiliği ve bürokrasi üzerinde yoğunlaşmıştır (Demir ve Yavaş, 2015: 92).

Bu çalışmanın çıkış noktası merkeziyetçilik ilkesinin yönetim sistemine yoğun bir biçimde hâkim olduğu bir ülkede vatandaşların siyasal katılıma ilgi göstermelerinin sebeplerini ortaya çıkartmak ihtiyacıdır. Bu bağlamda her faaliyetin merkezden yürütülüyor olması durumunda vatandaşları siyasal katılıma yönlendirecek veya uzaklaştıracak etkenler önem taşımaktadır. Kurgumuzu bir soru ile tamamlamak gerekirse şu sorunun cevabını aramak çalışmanın özünü oluşturmaktadır: "Tüm kamu hizmetlerinin tek bir merkezden planlanması durumunda siyasal katılımın hükmü nedir?”. Bu sorunun cevabı verilebilirse yönetim sisteminin merkeziyetçi veya adem-i merkeziyetçi yapılanması içerisinde siyasal katılım açısından farklı seçeneklerin varlığı

\footnotetext{
${ }^{1}$ Dr. Öğr. Üyesi, Tekirdağ Namık Kemal Üniversitesi, iiBF, Siyaset Bilimi ve Kamu Yönetimi Bölümü, konuralpdemir@yahoo.com.tr, yazar ORCID bilgisi: https://orcid.org/0000-0003-1199-930X.
} 
önem taşıyacaktır. Farklı bir bakış açısı ile merkeziyetçi yapılanma içerisinde siyasal katılımın alternatif yöntemleri de sorgulanacaktır. Eğer siyasal katılım için alternatif yöntemler yaratılabilirse merkeziyetçi yönetim anlayışının bilinen çözümler yerine farklı bir yöne doğru evrimleşeceği düşünülmektedir. Çalışmanın bir diğer sorusu da şudur: 'Devletin üniter yapısını ve merkeziyetçilik ilkesini koruyarak yönetimini tabana yayması mümkün müdür?' Bu sorunun cevabının ana kurgusu da çalışmanın bir diğer niteliksel özelliğini oluşturmaktadır. Bu çalışmada önerilen katılım seçeneklerinin farklı çalışmalar için bir ilham kaynağı olacağı düşünülmektedir. Bu bütünlük içerisinde çalışma kurgusal olarak üç bölümden oluşmaktadır. Birinci bölümünde merkeziyetçilik anlayışı, sebepleri ve sonuçları ile siyasal katılım konusuna değindikten sonra ikinci bölümde siyasal katılımın gerekliliği ve çeşitleri üzerinde durulacaktır. Üçüncü ve son bölümde ise siyasal katılım yollarına alternatif öneriler geliştirilmeye çalışılacaktır.

\section{Merkeziyetçilik Anlayışı, Sebepleri ve Sonuçları}

Merkeziyetçilik ilkesi üniter devlet yapılanmasının anahtar kavramıdır. Bu ilke yönetimi bir bütün halinde değerlendirmektedir (Güler, 2000: 29). Bu bağlamda merkeziyetçilik bir ülkenin kamuya ait olan kaynaklarının ve yetkilerin tümünün başkent ve ona bağlı yönetsel birimler tarafından kullanılması durumudur (Eryılmaz, 2012: 301). Böyle bir durumda kamu hizmetlerinin planlanması, yürütülmesi, denetlenmesi (Aydın, 2009: 186) ve kaynak kullanımı merkezi yönetime ait olmaktadır (Parlak ve Sobacı, 2012: 355).

Bir ülkenin yönetim düzeninin merkeziyetçi veya yerinden yönetim üzerine kurgulanmasında devletin yönetim gelenekleri, tarihsel ve coğrafi koşulları, sosyo-ekonomik yapısı, siyasi alışkanlıkları ve demokrasi bilinci etkili olmaktadır (Parlak ve Sobacı, 2012: 354-355).

Merkeziyetçilik uygulamalarının görüldüğü ülkelerde merkezi yönetim diğer bütün yönetsel birimler ile kıyaslandığında oldukça fazla güçlüdür. Bu güç kamu hizmetlerinin sunulması aşamasında ortaya çıkmakta ve bütün süreç boyunca etkili olmaktadır (Çevik, 2012: 83).

Merkeziyetçi yönetim anlayışı hâkim olduğu kamu yönetimi sisteminde çok sayıda soruna sebebiyet vermektedir (Parlak ve Sobacı, 2012: 355). Yönetim siteminin merkeziyetçilik anlayışına göre kurgulanması yönetimin ağır işlemesine, kırtasiyecilik uygulamalarına, bürokrasiye ve kamu hizmetlerinde verimsizliğe sebep olmaktadır (Aydın, 2009: 239; Parlak ve Sobacı, 2012: 355). Çünkü kamu hizmetlerini gerçekleştirmekten sorumlu olan memurlar her işlem için bir üst makama danışmak veya onay almak ihtiyacını hissetmektedirler. Bu durum belirli bir işlem sürecini almakta, kamu hizmetlerinde gecikmeler yaşanmakta ve ihtiyaçların yerel düzeyde olması gerektiği gibi yürütül(e)memesi sorununa sebebiyet vermektedir. Çünkü ihtiyaç sahibinin neye ihtiyaç duyduğunu ve bu konuda nelerin yapılması gerektiğini en iyi bilen ihtiyaç sahibine en yakın olandır. Bununla birlikte merkeziyetçi yönetim anlayışı siyasal katılımı azalttığı, halkı yönetimden uzaklaştırdığı ve pasif bir konuma getirdiği için demokrasinin temel ilkeleri ile uyumsuz bir yapı sergilemektedir (Parlak ve Sobacı, 2012: 355).

Merkeziyetçilik yapısı merkezde örgütlenen, kurallar bütünü içerisinde faaliyet gösteren ve bu yüzden de toplumla uzlaşma sorunları yaşayan "bürokratik toplum" yapısını meydana getirmiştir. Bu durum bir sorun olarak algılandığı takdirde çözüm önerisi olarak yönetime katılım sisteminin yeniden kurgulanarak modellenmesi önerilmektedir (Toprak, 2015: 27).

Karar verme yetkisinin en üst ve tek bir konumda toplanması ve yerel nitelik taşıyan hizmetlerin merkezi yönetim tarafından yürütülmesi sonucunda bürokrasi uygulamalarında artış gözlemlenmektedir. Aynı zamanda halkın kamu hizmetlerine olan ilgisi azalmakta, demokrasinin 
hareket alanı daralmakta ve hizmetlerin maliyetinde de artış(lar) gözlemlenmektedir (Ökmen ve Parlak, 2008: 40).

Merkeziyetçilik anlayışının yoğun bir biçimde yönetime hâkim olduğu ülkelerde halkın yönetime katılımı belirli sınırlar içerisinde kalmaktadır. Yönetim halkın talep ve beklentilerine karşı yeterli ölçüde duyarlı ol(a)mamakta ve taleplerin yerel düzeydeki çeşitliliğine uyum sağlayamamaktadır (Gül vd., 2014: 3).

Merkeziyetçiliği tek yanlı veya tek bir boyuttan değerlendirerek yalnızca olumsuzluklarına odaklanmak kavramın bütünselliğine zarar vermektedir. Dolayısıyla merkeziyetçiliği çift taraflı değerlendirmek gerekmektedir.

Bir devletin merkeziyetçilik anlayışı ve uygulamaları belirli durumlarda işlevsel olabilmektedir. Bu durumu kısaca açıklamak gerekirse niteliksel özellikleri birbirinden farklılık gösteren çeşitli toplumsal yapılanmaların karşılaşabileceği demokratik sorunların anlaşılabilmesi ve aşılabilmesi için merkeziyetçilik kavramının önem taşıdığı ifade edilebilmektedir. Bu önemin eyleme dönüştürüldüğü durumda merkeziyetçi yapılanma toplumsal farklılıkları bir bütün halinde değerlendirerek, herhangi bir çatışma ortamına fırsat vermeden toplumun yönetsel ve siyasal açıdan yeniden modellenmesi adına gerekli bir uygulama şekline dönüşebilmektedir. Bir diğer ifadeyle merkeziyetçilik farklılıkları çatışma ortamına girmeden bir araya toplamak ve dağılmalarına fırsat vermeden demokratik çözümler aramak için gerekli bir sonucu ortaya çıkartmaktadır (Yetiş, 2006: 280).

Türkiye'de merkeziyetçi bir yönetim anlayışı benimsenmiştir. Türkiye'nin yönetim sistemi ülkeyi tek bir merkezden yönetmek ve hükümet yetkisini çevreye dağıtmamak üzerine kurgulanmıştır. Yerel seviyede örgütlenmek ve belirli hizmetleri kendilerine tanınan sınırlar içerisinde özgürce yerine getirmek merkezi yönetimin kontrolü altında gerçekleşmektedir (Demir, 2014a: $62)$.

\section{Merkeziyetçiliğe Karşı Bir Çözüm Önerisi: Yerelleşme}

Yerelleşme kavramının ifade etmek istediği sonuç gerçekte çok basittir. Yerelleşme teknik olarak merkezi yönetim tarafından yapılması etkin ve verimli olmadığı düşünülen hizmetlerin yerel yönetim birimlerine terk edilmesidir. Ancak merkeziyetçilik anlayışının esnetil(e)mediği ülkelerde yerelleşme hedefinin gerçekleştirilmesi için girişilen çabalar sınırlı düzeyde kalmakta ve belirli bir aşamanın ilerisine geç(e)memektedir (Çevik, 2012: 87).

Dünya genelinde yaşanan hızlı değişim, bilginin üstün konuma gelmesi, demokratikleşme çabaları, insan haklarının önem kazanması ve çevre sorunlarının uluslararası alanda çözüm arayışları ve ulaşım ve iletişim alanındaki dikkat çeken ilerlemeler yönetim sistemlerinin merkeziyetçi yapılanmadan katılımcı ve yerelleşen bir seviyeye dönüşüm yapmasını zorunlu bir hale getirmiştir (Demir vd., 2011: 277). Bu açıdan değerlendirildiği takdirde yerelleşme ilkesinin katılımcı yönetim anlayışına fayda sağladığı ve hatta teşvik ettiği sonucuna varılabilmektedir (Ak$\tan , 2003:$ 93).

Yerelleşmenin kendisi için uygulama alanı bulduğu ülkeler yönetim sistemini katı bir merkeziyetçilik anlayışı üzerine kurgulamamışlardır. Bu tür ülkeler genel olarak federal bir yapıya sahip olmaktadırlar. Dolayısıyla yerelleşmenin liberal ve federal devlet sistemleri içerisinde hareket kabiliyeti son derece yüksektir. Çünkü merkeziyetçilik ilkesinin öğretilerine göre faaliyet gösteren bir devlet bürokratik yapılanma içerisinden dışarıya çıkamamakta ve yetkilerin yerel düzeydeki yönetim birimlerine aktarılmasına karşı direnç göstermektedir (Yaman, 2015: 256-257). 
Yerelleşme sonucunda güçlenen yerel topluluklar ile birlikte ekonomi, demokrasi, kültürel değerler ve sosyal kalkınma alanlarında da bir değer artışı yaşanmaktadır. Dolayısıyla yerel yönetimlerin güçlenmesi ulus devletin felaketi olacaktır öngörüleri gerçekçi bir sonucu ortaya çıkartmamaktadır. Çünkü yerel halkın çıkarları yerel yönetimler tarafından koruma altına alınmaktadır ve böylece yerel düzeydeki kamu yararı da korunmuş olmaktadır. Aynı zamanda yerelleşmenin önem taşımasının bir diğer sebebi de kamu yönetimi sistemi içerisinde yerel yönetimlerin önemli bir ağırlığının bulunmasıdır (Çukurçayır, 2013: 37-38). Yerel yönetimlerin taşımış oldukları değeri yüceltebilmek için bir ilke haline getirilen yerelleşme kavramının özünde "zirveye rağmen tabanı tercih etme" düşüncesi bulunmaktadır. Bu düşüncenin nihai hedefinde ise görevlerin yerine getirilmesi adına yetkilerin uygulanması için "ısrarla" uygun yönetim biriminin aranması gerekliliği yer almaktadır. Kamu hizmetlerinin sunumu aşamasında alt düzey yönetim biriminin yetersiz kalması durumunda daha kaliteli ve adaletli hizmet sunumu için yetkilerin bir üst birim tarafından kullanılması ve kamu hizmetlerini sunması kabul görmektedir (Toprak, 2006: 14-15).

Yerelleşmenin kurgusunu merkeziyetçilik ilkesine sıkıca bağlanmış bir devlet düzeni veya yönetim sistemi içerisinde çözümleyebilmek oldukça zordur (Toprak 2006: 17). Bu bağlamda merkeziyetçilikten uzaklaşma fikri aynı kurumlar arasında yetkinin bir alt basamağa iletilmesi ve farklılaşmış yönetim birimleri arasında yetkinin halka en yakın olana teslim edilmesi kapsamında şekillenmiştir (Bilgiç ve Gül, 2009: 620). Dolayısıyla kamusal hizmetlerin yerel ve genel nitelik taşıyıp taşımadığına bakılmaksızın ağırlıklı olarak merkezi yönetim tarafından yerine getirilmeye veya koordine edilmeye çalışılması yerine yerel niteliği ağır basan hizmetlerin tamamının yerel yönetimler tarafından yerine getirilmesi kabul gören bir gerçektir (Çevik, 2012: 95).

\section{Türk Kamu Yönetiminde Siyasal Dönüşüm}

Türk kamu yönetimi için bilinen kalıpların dışına çıkarak yeni siyasal bir dönüşüm içerisine girmek "sivilleşmek" ve "demokratikleşmek" adına önem taşımaktadır. Mutlak hedef olarak benimsenen nihai varış noktasında yerelleşme idealini sivilleşmek ve ardında da demokratikleşmek için aracı bir unsur olarak kullanmak mümkündür (Aktan, 2003: 93).

Bu çalışmada bir yönetim sisteminin öncelikle sivilleşmesi gerekliliği artı bir değer olarak ortaya çıkartılmaya çalışılmaktadır. Çünkü ana kurgunun ekseninde hareket etmek gerekirse, sırası ile demokratikleşmenin ve yerelleşmenin, sivilleşmenin ardından kendiliğinden ve fazladan bir çaba harcamadan ortaya çıkacağı düşünülmektedir. Sivillik idealinin uygulamaya yansıtılabildiği ölçüde demokratik ve yerelleşmiş bir düzene geçilebilecek ve her birey siyasal bir aktör haline dönüşebilecektir. Bu sebepten dolayı sivilleşme birinci sırada değerlendirilmesi gereken önemli bir başlıktır.

Sivil bir ideale sahip olmak ve bu idealin ana kurgusu etrafında hareket etmek mutlak kudret sahibi devletin karşısında bireylerin ve bireylerin özgürce oluşturduğu örgütlü birlikteliklerin hareket alanını genişletmek ve bu değerlere manevra kabiliyeti kazandırmak anlamına gelmektedir (Aktan, 2003: 93).

\section{Siyasal Katılım}

Siyasal katılımdan söz edildiğinde genel olarak halkın katılımından değil, özel sektör, örgütlü gruplar, kamu kurum ve kuruluş temsilcilerinin katılımından söz edilmektedir. Bu durum da katılımın çevresel boyutunu daraltmaktadır. Katılım konusunda yapılan düzenlemelere ve oluşturulan katılım araçlarına ve kurumlarına rağmen mevcut durumda halkın etkin katılımını sağlayabilecek bir sonucun ortaya çıkartıldığından söz etmek oldukça zordur (Gül vd., 2014: 6-19). 
Siyasal katılımın kurgusu yönetimin halka dayandırılması gerekliliği üzerine inşa edilmiştir. Bu fikrin yaygınlaşmaya başladığı günden itibaren halk gruplar ve topluluklar halinde siyasete katılmak için çaba sarf etmektedir. "Halk" unsuru siyasal katılım fikrinin temel dayanak noktasını oluşturmaktadır (Kapani, 2010: 143). Bu şekilde bir çıkarım yapmak halkın siyasetin ve yönetimin odak noktasında yer aldığını vurgulamak açısından önem taşımaktadır.

Yerel yönetim geleneğinin kuvvetli ve köklü olmadığı ülkelerde halkın yönetimin faaliyetlerine karşı duyarsızlığı söz konusudur. Böyle bir durumda halkı yönetime dâhil etmek oldukça zordur. Bu sorunun çözüm yolu ise yerel iletişimden geçmektedir. Katılım belediye organları ile halk arasında sürekli bir iletişimin varlığı ile sağlanabilecektir. Dolayısıyla iletişim kanallarının açık tutulmadığı veya böyle kanalların hiç var olmadığı bir yönetim sisteminde halkın katılımı olgusu herhangi bir anlam ifade etmemektedir (Polatoğlu, 2003: 170).

Bir toplum içerisinde farklı inanışların, farklı yönelişlerin ve farklı düşüncelerin var olması kabul edilebilir bir gerçekliktir. Ancak farklııkların her zaman birbirleri ile uyumunu sağlamak kolay bir iş değildir. Uyumlaştır(a)mama sorunu çatışma olumsuzluğunu da beraberinde getirmektedir. Çatışma demokrasinin çizmiş olduğu sınırlar içerisinde kaldığı sürece, farklılıklardan kaynaklanan bir zorunluluk nitelemesiyle kabul görmektedir. En azından bu şekilde adlandırılabilmektedir. Çünkü güçlü demokrasi çatışmayı kabul eden bir kurguya sahiptir ve sonuç itibarıyla çatışma ayrışmayı değil, birlikteliği ve işbirliğine dönüşmek için bir fırsatı ortaya çıkartmaktadır. Bunun için çeşitli yöntemlerin kullanılması ve bu yöntemlerin çatışmayı kamu yararına dönüştürmesi gerekmektedir (Çukurçayır, 2012: 32).

Bireylerin farklı toplumsal rollerinin yanında siyasal görevler üstlenmeleri, siyasal bir kişilik oluşturmaları ve bu amaçla çeşitli eylem ve davranış kalıpları içerisine girmeleri "siyasal katılma" kavramı ile açıklanan sonuçları ortaya çıkartmaktadır. Bu bağlamda siyasal katılma tanımsal boyutu ile bir davranış ve eylem bütünlüğüdür. Aynı zamanda bireylerin yerel ve ulusal alanda kendi çıkar ve menfaatleri doğrultusunda kendi yöneticilerini seçmek için giriştikleri faaliyetlerin bütünüdür (Dursun, 2012: 233-234).

Siyasal katılım toplumsal açıdan değerlendirildiği takdirde kaynak ayırma ve bütünleştirme kavramlarını bir araya getiren bir işleve sahiptir. Bu bir bakıma toplumun kaynak dağılımına olan talebini yeniden değerlendirmek anlamına gelmektedir. Diğer yandan ise farklı süreçlerin yer aldığı bir sistem içerisinde farklılıkları aynı yöne doğru yönlendirebilmek için katılım konusu bütünleştirici veya birleştirici bir etken olarak görev yapmaktadır. Bir diğer ifadeyle siyasal katılım “dengeli ve kararlı" bir yönetim sisteminin gerekleri arasındadır (Uysal, 1984: 112).

\section{Siyasal Katılımın Gerekliliği Üzerine}

Demokrasinin işlevselliğini sağlayabilmek için faydalanılan en etkili araçlardan birisi siyasal katılımdır. Siyasal katılımdan söz edilince en basit bir biçimde anlaşılan sonuç seçimlere katılarak oy kullanmaktır. Katılım bireyin var olabilmek için sürdürdüğü mücadelenin sosyal ve siyasal boyutunu oluşturmaktadır. Demokratikleşme uğraşlarının kökenlerine halkın kendi içerisinde gerçekleştirmeye çalıştığı amaçların kurgusunda rastlanılmaktadır. Katılım bireylerin sosyalleşebilmesi için gerekli olan hukuksal zemini oluşturmaktadır. Toplum tarafından benimsenecek bir kararın somut delilleri yalnızca siyasal katılım kanalı ile sağlanabilmektedir. Böylece toplumsal bir akıl ortaya çıkmış olacaktır (Çukurçayır, 2012: 33-34).

Siyasal sistem bireylerin yaşamları üzerinde doğrudan etkisi bulunan bir bütünlüğü oluşturmaktadır. Böyle bir bütünlük içerisinde siyasal roller üstlenen, siyasal davranışlar sergileyen ve 
siyasi eylemlerde bulunan bireyin öncelikli olarak bilmesi gereken siyasal sürecin kendi geleceklerini doğrudan etkileyecek bir niteliğe sahip olduğudur. Siyasal iktidarın bu süreç sonucunda almış oldukları kararların tamamının bireylerin mevcut ve gelecekteki yaşantılarını doğrudan etkileyeceğini bilmeleri siyasal katılımı daha işlevsel bir hale getirmektedir (Dursun, 2012: 233).

Siyasal katılım yönetim birimleri arasındaki ilişkilerin düzenlenmesinde önemli görevler üstlenmektedir. Bununla birlikte vatandaşların yaşadıkları yere ait oldukları düşüncesini geliştirebilmeleri ve yönetimin gerçekte kendisine ait olduğu bilincine varmaları katılım yolu ile sağlanmaktadır. Çünkü siyasal katılım yerel düzeyden başlayarak genele yayılan bir düzende yönetimin denetlenmesi ve yönetimin halkın çıkarlarına aykırı eylemlerde bulunmamasını garanti altına alarak sosyal yaşam seviyesinin artış göstermesinde etken unsur olarak görev yapmaktadır (Demir vd., 2011: 339).

Siyasal katılımın arttırılması için seçenin veya yönetilenin seçilen veya yöneten karşısında güç kazanması önem taşımaktadır. Çünkü siyasal katılım ve buna bağlı olarak da toplumsal ilişkiler toplumun dinamiğinin yalnızca belirli bir grubun elinde olduğu bir sistemde herhangi bir anlam ifade etmemektedir. Siyasal katılımın işlevsel bir hale getirildiği bir toplumda demokrasi olgusu da kendisine hareket edebileceği uygun bir zemine kavuşmuş olmaktadır. Bir diğer ifadeyle demokrasinin yerelleşmesi siyasal katılımın uygulanabilirlik düzeyi ile yakından ilişkilidir (Karaçor, 2009: 126-127).

Yerel halkın kendi sorunlarına çözüm üretebilmek için yönetimde yer almak isteğinde bulunması kabul edilebilir bir taleptir. Bu talebin hem yönetsel hem de siyasal yararları bulunmaktadır. Çünkü yerel halk yerel düzeyde gerçekleştirilecek bir faaliyete katılmak için kolay bir biçimde bir araya gelebilmektedir. Dolayısıyla yerel halkın bu isteğinden ve potansiyelinden faydalanmak kaynakların daha etkili ve verimli bir biçimde kullanılabilmesi için bir fırsat niteliğindedir (Keleş, 1995: 3-4). Bu fırsat siyasal katılımın gerekliliğinin de bir parçasını oluşturmaktadır.

Siyasal katılımın vatandaşlar ve yöneticiler açısından yararları bulunmaktadır. Bu yararlar aynı zamanda siyasal katıımın gerekliliğini de vurgulayan sonuçları ortaya çıkartmaktadır. Bu bağlamda siyasal katılım vatandaş yararı açısından değerlendirilecek olunursa her şeyden önce yaşanan süreçlerden en iyi bir biçimde bilgilenme sağlanmış olacaktır. Bununla birlikte siyasal katılım vatandaşların görüş, istek ve şikâyetlerini yöneticilere iletmesinde, toplumsal bütünleşmenin ve hoşgörünün oluşturulmasında, yeni plan, proje ve politikaların oluşturulması ve uygulanmasında vatandaşlardan destek alınmasında ve karar alıcıların hesap verebilirliğinin aktif bir hale getirilmesinde etkili görevler üstlenmektedir. Siyasal katılımı yöneticiler açısından değerlendirmek gerekirse genel anlamda toplumsal rızanın elde edilmesi üzerine kurgulanan sonuçlar ile karşılaşılmaktadır. Buna göre yöneticiler açısından siyasal katılım vatandaşları en iyi biçimde bilgilendirmede, vatandaşlar ile yakın bir iletişime girilmesinde, devlet ile vatandaş arasındaki engellerin kaldııılmasında, alınan kararlar hakkında vatandaş desteğinin alınmasında ve bu konuda maliyetlerin düşürülmesinde ve toplumsal uyumun geliştirilmesinde görev almaktadır (Löeffler vd., 2012: 11).

\section{Siyasal Katılımın Hareket Aktarma Organı Olarak Yerelleşme}

Toplumun işleyen siyasal sürece katılımının gerekliliği konusunda girişilen çabaların sonucunda toplumsal katılımı sağlayabilmek için devlet tarafından bir takım tedbirler alınmıştır. Bilgi edinme hakkının kullanılabilir bir hale getirilmesi, karar alma süreçlerinin şeffaf bir düzeyde sürdürülmesi ve toplumun katılımının yasal bir zemine oturtulması için çeşitli mevzuat düzenlemelerinin yapılması zorunludur. Bu zorunluluğun temel hedefinde siyasal katılımı işlevsel bir hale 
getirmek amacı yer almaktadır. Bu amacın gerçekleştirilebilmesi için de merkezi yönetimde toplanmış yetkilerin yerel düzeye indirilerek yerel yönetimlere devredilmesi gerekmektedir (Löeffler vd., 2012: 9).

Siyasal katılım ile yerelleşme arasında birbirlerini destekleyen ve birbirlerine ihtiyaç duyan karşılıklı bir ilişki söz konusudur. Farklı bir açıdan değerlendirmek gerekirse yerelleşmenin etkili bir biçimde uygulandığı bir yönetim sistemi içerisinde siyasal katılım kendiliğinden ortaya çıkmaktadır veya en azından varlığını zorunlu bir hale getirmektedir. Yerelleşme halka en yakın yönetim birimlerine kaynak, güç ve yetki verilmesi gerekliliğine vurgu yaparak ve gerekli olan faaliyetlerin yapılması adına eyleme geçilmesini sağlayarak siyasal katılımın gelişme gösterebilmesi için düşünsel ve hukuksal alt yapıyı da oluşturmaktadır. Aynı zamanda halkın siyasal katılıma özen göstermediği ülkelerde yerelleşme halkı yönetime ortak etmek için önemli bir basamak görevini de üstlenebilmektedir (Demir vd., 2011: 339). Bununla birlikte yerelleşme toplumun taleplerini en kolay bir biçimde yönetime iletebilmeleri için devlet ile vatandaş arasındaki mesafeyi ölçülebilir bir seviyeye getirmektedir. Yerelleşme, karar alma aşamasında vatandaşların taleplerinin dikkate alınması, demokratikliğin sağlanması, vatandaş odaklı olunması ve siyasal katılımın sağlanması üzerine yoğunlaşmaktadır (Demir, 2014b: 157). Yerelleşme sonucunda halkın kamu hizmeti üretimine ve sunumuna katılması kamu hizmetlerinin halkın beklentileri doğrultusunda şekillendirilmesini sağlamaktadır (Göküş vd., 2013: 32).

Yerelleşmede merkezi yönetim ile yerelin konumları yer değiştirmektedir. Yerel ikincil konumdan sıyrılarak birincil konuma geçmekte ve bu da mutlak güce sahip olan devletin veya merkezi yönetimin gücünün yerelin lehine sınırlandırılması anlamına gelmektedir (Keleş, 1995: 4-5).

Yerel yönetimler siyasal katılımın kolay bir biçimde uygulamaya geçirilebileceği birinci dereceden önemli kurumlar olmasında dolayı katılım konusunda yapılan bilimsel çalışmalar için yerelleşme kavramı vazgeçilemez bir değer taşımaktadır. Yerelleşmeyi başarabilmiş bir yönetim sistemi içerisinde halk siyasal açıdan aktif bir kimliğe sahip olmakta, yöneticiler tarafından dinlenmekte ve gerektiği durumlarda kendisine danışılan bir özne haline dönüşmektedir (Yaylı ve Eroğlu, 2015: 507).

Siyasal katılıma hareket kabiliyeti kazandırmak için yalnızca yerelin ve yerel halkın kuvvetlendirilerek merkeziyetçilikten uzaklaşılması yeterli değildir. Yerele fazladan sorumluluklar vererek yerel yönetimlerin gelişmesini beklemek gerçekçi sonuçların ortaya çıkması için kabul edilebilir bir davranış değildir. Diğer bir ifadeyle yerel yönetimlerin gelişmesi ile sorumluluklarının fazla olması arasında herhangi doğru orantı bulunmamaktadır. Yerel yönetimlerin gelişmesinin sağlanabilmesi ve halkın yönetime işlevsel bir biçimde katılımının sağlanabilmesi için devletin hiyerarşisi dışında yer alan örgütlenmelere destek verilmesi gerekmektedir. Bu bağlamda yerel halkın siyasi süreçte yer alabilmesi için gerekli olan yerelleşme yardımı ile zenginleştirilmiş demokratik zeminin hazırlanması önem taşımaktadır (Gül vd., 2014: 4).

\section{Siyasal Katılımın Alternatif Yolları}

Siyasete katılma farklı düzeylerde ve şekillerde gerçekleşebilmektedir. Bu çeşitliliği bir sıraya koymak gerekirse en alt basamakta gazete, dergi, televizyon ve radyo aracılığı ile güncel siyasal süreci takip etmek yer almaktadır. Bu süreç bireyin olaylar karşısındaki "seyirci faaliyeti" şeklinde değerlendirilebilmektedir. İkinci basamakta ise siyasal kararlara karşı tepki gösterebilmek içgüdüsü ile harekete geçme durumu söz konusudur. Bu basamakta birey siyasi düşüncelerini 
açıklamak için gazetelerde yazı yazabilir, radyo ve televizyonda konuşabilir, siyasi parti başkanları ile görüşerek düşüncelerini onlara aktarmaya çalışabilir ve istediği siyasi partiye üye olabilir ve maddi bağışlarda bulunabilir. Üçüncü ve en üst basamakta ise birey artık aktif bir katılımcı konumundadır. Bu konumda birey siyasi bir partinin başkanı veya aktif bir üyesi olabilmekte, seçimle göreve gelinebilecek görevlere aday olabilmekte, seçildiği durum(lar)da görev yapabilmekte ve seçim kampanyalarında aktif görev(ler) alabilmektedir (Kapani, 2010: 145).

Yukarıda ifade edilen unsurlar bilinen katılım yollarını meydana getirmektedir (Kapani, 2010: 145). Ancak farklı katılım yollarının var olabilme ihtimaline bağlı olarak yerelleşme yeni bir kurgu için etken bir unsur olarak var olmaktadır.

Yerelleşmeden önemli derecede etkilenmesi sonucunda yerel demokrasinin gelişmesi için yeni bir kurgu içerisine giren halkın kendi kendisini temsil etmesi düşüncesi, temsili demokrasinin işlevsellikten uzaklaştığı bir alanda, doğrudan temsilin izlerini araştırmak için önemli bir sebebi ortaya çıkartmaktadır. Bu sebep "temsili demokrasi krizi” şeklinde kendisini göstermektedir. Temsili demokrasinin yönetim alanında yaşanan sorunlara beklenilen düzeyde çözüm üret(e)memesi karşısında yerelleşme yerel katılımın güçlendirilmesi gerekliliğini ileri sürmektedir (Önder, 2013: 312).

Yerel düzeyde yönetime katılım konusunda değişik yöntemler bulunmaktadır. Yerel kamuoyu yoklamaları ve araştırmaları, halkoylamaları, kamusal toplantılar, yerel düzeyde konumlanmış sivil toplum örgütlerine katılım, kent yönetimi ve uygulamaları hakkında yargı organına başvurma ve kent konseylerine katılım gibi yöntemler farklı ülkeler tarafından kullanılmaktadırlar (Adıgüzel, 2003: 49).

Yerelleşme modern dönemde merkezi yönetimin elinde bulunan kaynak oluşturma ve aktarma, karar alma ve uygulama ve kamu politikaları üretme gibi yetkilerin merkezi yönetimin hiyerarşisi dışında kalan yönetim birimlerine ve sivil topluma aktarımı gerektirmektedir. Bu açıdan değerlendirildiği takdirde yerelleşme sivilleşmenin anahtar kavramı haline gelmiş durumdadır (Bilgiç ve Gül, 2009: 621).

Siyasal katılımın en bilinen ve kolay örneği oy kullanmaktadır. Vatandaşlar belirli dönemlerde oy kullanarak kendilerini yönetecek kadroları seçmekte ve bu şekilde siyasal sürece katıIım sağlamış olmaktadırlar. Ancak bu kısa süreli eylem demokratikliğin sağlanabilmesi adına yeterli değildir. Seçimlerin siyasi partilerin birbirleri ile yarıştığı bir faaliyet haline dönüşmesi vatandaşları farklı arayışlara yöneltmiştir. Vatandaşlar dilekçe yazmak, telefon etmek, faks çekmek, elektronik posta yolu ile ileti göndermek ve birebir görüşmeler yapmak vasıtasıyla yönetimi etkilemeye çalışmaktadırlar. Bu yöntemler olağan eylemler olarak değerlendirilebilmekle birlikte boykot, sivil itaatsizlik, gösteri yürüyüşleri, işgal ve sokak çatışmaları da olağandışı katılım yolları şeklinde değerlendirilmektedir (Dursun, 2012: 238-239). Bu noktada önem taşıyan husus vatandaşların bir şekilde seslerini yönetime duyurma ve istediklerini yönetime kabul ettirebilme çabasıdır. Dolayısıyla siyasal katılım yöntemleri yukarıda sayılan olağan ve olağandışı yöntemler ile sınırlandırılmış değildir. Bu bağlamda farklı katılım yöntemleri üretilebilmektedir.

\subsection{Mahalle Düzeyinde Seçim Yöntemi}

Belediye meclisi yerel seçimler sonucunda göreve gelmiş üyelerden oluşmaktadır. Ancak seçim sisteminden kaynaklanan sebeplerden dolayı meclis üyesi ile halk arasında iletişimsel bir kopukluk yaşanmaktadır. Çünkü belediye meclis üyeleri ilgili kentin tamamından gelen oyların bir bütün halinde değerlendirilmesi sonucunda seçilmektedirler. Bir diğer ifadeyle kent tek başına bir seçim bölgesidir. Siyasi partiler meclis üyesi adaylarını liste halinde toplu bir biçimde ve 
kentin tamamı için aday göstermektedirler. Dolayısıyla meclis üyeleri kentin bir mahallesini simgelemek amacıyla göreve getirilmediği için normal bir vatandaş ile seçilmiş meclis üyesi arasında herhangi ortak bir bağ bulunmamaktadır. Bu sorunun üstesinden gelebilmek için belediye meclis üyelerinin mahalle düzeyinde seçilmesi yönteminin benimsenmesi gerekmektedir (Polatoğlu, 2003: 170-171). Mahalle biriminin yerel ile bütünleşmesi toplumun demokratik değerlere sahip çıktığının ve sivil bir düşüncenin meydana geldiğinin en önemli kanıtı niteliğindedir (Şahin ve Işık, 2011: 222).

Mahalle birimleri önemli ölçüde komşuluk ilişkileri ve bireysel yakınlığa dayalı bir yapılanmaya sahiptirler. Mahalleler bireylerin kendileri hakkında alınacak kararlara aracısız katılabildiği / katılabileceği ve günlük yaşamı doğrudan etkileyen faaliyetlerin gerçekleştirildiği yaşamsal alanlardır. Bu nitelikleri ile mahalle "birinci basamak yerel yönetim" nitelemesine de sahiptir. Bu sebepten dolayı mahalle düzeyinde katılımcı sistemlerin oluşturulması siyasal katılım adına önem taşımaktadır (Emrealp, 2010: 46).

Mahalle düzeyinde gerçekleştirilecek herhangi bir çalışma veya kamusal faaliyet halkın yaşadıkları mekâna ve geniş anlamda ise kentin tamamına sahip çıkma duygusunun geliştirmesi açısından önem taşımaktadır. Bu sayede "kentlilik" bilinci gelişme gösterecek, kentsel hakların ve kentlinin kent yaşamındaki sorumlulukları daha bilinçli bir biçimde kavranacak, kendileri adına başlatılan işlere doğrudan katılım sağlanabilecek ve bireylerin sorumluluk duygusu ile yüklenmesine olanak tanınmış olacaktır. Böylece etkin ve demokratik bir katılım sistemine sahip olunabilecektir (Emrealp, 2010: 46).

Mahallenin siyasal katılım konusunda işlevsel bir hale getirilebilmesi için mahalle düzeyinde örgütlenilmesine ve mahalle meclisleri gibi demokratik yapılanmaların kurularak aktif bir biçimde faaliyet göstermesine olanak tanınması gerekmektedir (Alada, 2008: 9). Çünkü mahalle halkın yönetime katılabileceği en alt yönetim kademesidir. Bu yönetim kademesi ne kadar işlevsel bir hale getirilebilirse demokrasi de o ölçüde yerel düzeyde hareket kabiliyeti kazanabilecektir. Sonuç itibarıyla demokrasinin uygulama aracı olan yönetime katılım olgusu mahalle düzeyinde daha kolay bir biçimde uygulanabilmektedir (Erdagöz, 2012: 60).

\subsection{Doğrudan Siyasal Katılım Yöntemi: Sivil Katılım}

Merkeziyetçi anlayış ile yönetilen bir devletin temel amacı toplumu kontrol etmek ve devleti topluma karşı korumaktır. Devlet, bu amaç doğrultusunda yönetim sistemini şekillendirmektedir. Dolayısıyla merkeziyetçiliğin yoğun bir biçimde yaşandığı bir ülkede yerinden yönetim, yetki devri ve sivillik kavramları açık bir biçimde tasvir edil(e)memektedir. Bu noktada önemli olan husus kapalı tutulan veya üzerinde çok fazla tartışılmayan konuları açıklığa kavuşturmaktır. Günümüz uygulamalarında önem taşıyan "devlet merkezli" olmak değil, "birey/vatandaş merkezli" olmaktır. Bunu başarabilmek için de yönetim sistemini adem-i merkeziyetçiliğe doğru geçiş yaptırmak ve sivil toplumu yönetim sisteminin aktif bir unsuru haline getirmek gerekmektedir (Eryılmaz, 2012: 303).

Siyasal katılımın, yalnızca belirli dönemlerde oy kullanmak yöntemi ile sağlanabileceği anlayışı katılım kavramının gerçek hedefini ortaya koymamaktadır. Katılım siyaset ile bütünleştirilmesi sonucunda dar bir alana sıkışmaktadır. Dolayısıyla yönetimin alacağı kararlara katılma ve yönetime ortak olma çabalarının eylemsel niteliğini ifade eden katılma kavramının (Alkan, 2000: 58) işlevselliğinin sağlanabilmesi için yeni modellerin geliştirilmesi önem taşımaktadır.

Çağdaş demokrasilerin ilgilenmesi gereken en önemli sorunlardan biri halkın siyasal sürece yabancılaşması ve ilerleyen zaman içerisinde ise ilgisini tamamen kesmesidir. Bu noktada sivil 
toplum halk ile siyaset arasında gevşeyen ve kopan bağları onarmak için ortaya çıkan etken bir unsurdur. Sivil toplum halkın süreç içerisinde kalabilmesi için farklı yöntemler sunmaktadır (Kıvanç, 2011: 20; Karar Alma Sürecine Sivil Katılım İçin İyi Uygulama İlkesi, 2009: 10).

Seçilmiş kişilerin politika belirleme ve uygulama aşamasında kendilerini seçenleri süreç dışarısında bırakmaması düşüncesinin genel kabul görmesi üzerine sivil toplumun katılımcılığı demokratik düzeyde şekillendirebileceği görüşü yaygınlık kazanmıştır. Katılımcı demokratik bir yönetimin varlık kazanması için sivil toplumun işlevsel bir araç olarak kabul edilmesi sonucunda ulusal ve yerel düzeydeki yönetim birimleri karar alma aşamasına halkı da dâhil edebilmek için çeşitli yöntemler üretmeye çalışmışlar ve yeni yapılanmaların benimsenmesini bir kural niteliğinde kabul etmişlerdir (YASADER, 2008: 3).

Sivil toplumun modern anlamda kurgulanmaya başlandığı 12. yüzyılda, ticaretin yaygınlık ve güç kazanması ile birlikte esnaf gibi küçük ticaret çevreleri feodal yapıdan sıyrılarak özgürleşmiş veya özgürlük çanlarının çaldığı kentlerde önemli konuma gelmeye başlamışlardır. Bu gelişim sivilliğin artık tanımsal boyuttan değerlendirilmesi için önemli bir başlangıç noktasını oluşturmaktadır. Bu dönemden başlayarak sivil toplum gelişen dünyada merkezi yönetimin karşısında bağımsız bir biçimde örgütlenen ve özerk olmayı başarabilen bir birliktelik haline evrimleşmiştir (Demir, 2014a: 62).

Sivil toplum bireylerin hak ve özgürlüklerini savunabildikleri bir alan olarak çoğulculuk ve katılım değerleri üzerinde yükselmektedir. Bu bağlamda her şeyi devletten beklemek düşüncesi yerini katılımcı sivil toplum idealine terk etmeye başlamıştır (Özgişi, 2014: 57). Bu idealin gerçekleştirilebilmesi adına sivil toplumun kamu yönetimi birimleri içerisinde örgütlenebilmesinin yolunu açmak gerekmektedir. Bir diğer ifadeyle sivil toplum politika belirleme, onaylama, reddetme ve değiştirme haklarına sahip olabilmesi ve süreci yönlendirebilmesi için çeşitli komiteler altında kamu yönetimi sistemi ile bütünleşmesi önem taşımaktadır (YASADER, 2008: 7). Çünkü sivil toplum açısından toplum normatif anlamda iktidar adayı veya ortağı değil, siyasal süreci dışarıdan yönlendiren bir anlayışın somutlaşmış biçimidir. Bu bağlamda temel amaç devleti bir sivil toplum devleti haline getirebilmektir (Ataay, 2006: 126).

Sivil katılım sivil toplum ile kamu gücü arasında bir iletişimi zorunluluk haline getirirken hukukun üstünlüğü ilkesi de işlevsel görevler üstlenmektedir. Siyasi iradenin temel demokratik değerlere bağıılık göstermesi, gerekli olan mevzuat kaynaklarının tamamlanması ve diyalog için uygun bir ortamın yaratılması sivil katılım zemininin oluşturulabilmesi için mutlak bir biçimde gereklilik taşımaktadırlar (Kıvanç, 2011: 21).

\subsection{Sivil Diyalog}

Diyalog ortak çıkar ve hedeflere ulaşabilmek için karşılıklı ve sürekli olmak üzere iletişim kurmak anlamına gelmektedir. Diyalog mutlaka iki yönlü olmak zorundadır. Sağlıklı bir diyaloğun gerçekleştirilebilmesi için karşılıklı anlayış, birbirine duyulan saygı ve güven ve geri dönüş sistemlerinin oluşması gerekmektedir. Bununla birlikte sivil diyaloğun sağlanabilmesi için gerekli olan teknik ve sosyal alt yapı sistemleri ve gerekleri şu şekilde sıralanabilmektedir (YASADER, 2008: 11-12):

- Illgili tarafların görüşlerini açıklayabilecekleri ve birbirleri ile iletişim kurabilecekleri toplantıların düzenlenmesi,

- Kamu yetkilileri ile sivil toplum temsilcilerinin karşılıklı olarak görüş alış verişinde bulunabilecekleri oturumların gerçekleştirilmesi,

- Tartışma ortamlarının yaratılabilmesi amacıyla internet imkânlarının kullanılması, 
- Bu konuda çalışacak veya mevcut durumda çalışan kamu birimlerinin ve sivil toplum örgütlerinin işlem kapasitesinin genişletilmesi,

- Tarafların birbirlerini daha iyi anlayabilmesi ve değerlendirebilmesi amacıyla karşılıklı olarak değişim programlarının uygulanması,

- Uzmanların katılacağı seminer ve toplantıların düzenlenmesi,

- Konu hakkında tavsiye verebilecek ve yönlendirme sağlayabilecek bir komisyonun kurulması gerekmektedir.

Sivil diyalog veya diğer ifadesiyle sivil toplum diyaloğu gerçekte Avrupa Birliği (AB) teknik katılım müzakerelerini tamamlamayı amaçlayan bir politikadır. Bu bağlamda değerlendirildiği takdirde sivil diyalog Türkiye ile $A B$ vatandaşlarının birbirlerini daha iyi anlayabilmeleri için uygun bir ortamı yaratmayı hedeflemektedir. Sivil diyalog farklılıkların birbirlerini tanımları ve görüş açılarını genişletmeleri bakımından oldukça fazla önem taşıyan bir kavramdır (Vögele, 2007: 8).

\section{Hayali Kurulan Devletin Ana Kurgusu}

Hayali kurulan ideal devletin nasıl olması gerektiği konusunda henüz mutlak bir cevap bulunmuş değildir. Böyle bir soruya cevap arayışı Sokrates ve öğrencisi Eflatun'un ile birlikte başlamış ve günümüze kadar devam etmiştir. (Aktan, 2003: 115). Peki sonuç nedir? Sonuç mevcut durumda tartışma aşamasındadır. Aşağıda açılan başlıklar hayali kurulan devletin hareketli parçalarını oluşturmaktadır.

Sivil Devlet: Devletin sivilleşmesinden amaçlanan kamu yönetimi sisteminin aşırı merkeziyetçilik uygulamalarından ve bürokrasi adetlerinden uzaklaşarak daha esnek bir yapıya sahip olması ve böylece vatandaşların yönetimde söz sahibi olmalarının yolunun açılmasıdır. Bu amaç bir ideal olarak kabul edilebilmektedir. Bu idealin gerçek anlamda uygulamaya yansıtılabilmesi için de yönetişim, yerelleşme, yerel olma, yerelden yönetim ve sivil toplum kavramlarını taşıdıkları anlamlarından soyutlamadan yeniden kurgulayarak bir bütün haline getirilmesi önem taşımaktadır. Çünkü bu kavramların hepsi aslında ortak bir hedefe kilitlenmiş durumdadır (Demir ve Yavaş, 2015: 105).

Sivil devlet anlayışı siyaseti ve ekonomiyi ahlaki bir zeminde demokratikleştirebilmekte ve sivil toplumun sosyal ilişkilerini özümseyebilmektedir. Bu anlayış içerisinde çeşitli grupların ve kuruluşların (dernek, birlik veya ortaklık) uygun bir biçimde fonksiyon göstermesi ve demokrasiye ve piyasa ekonomisine aktif katılımının sağlanması zorunludur (Pabst, 2012: 190).

Sivil Yönetişim: Kamu yönetiminin önceden çizilmiş sınırlarını aşabilmesi için kalıp değerlerden uzaklaşılarak yeni bir kurguya yer açılması gerekmektedir. Bu kurgu da yönetişim kavramı özelinde çerçevelenebilmektedir. Çünkü yönetişim katı ve bürokratik yönetim yerine sivil yönetimi önermekte, halkın yönetimde söz sahibi olabilmesinin yollarını araştırmaktadır (Demir ve Yavaş, 2015: 102).

Yönetişim siyasi otoritenin hiyerarşik ve tek tip egemenlik varlık sahasını sorgulamaya açmakta ve bilinen kalelerini yıkmaktadır. Böylece devlete yeni bir bakış açısını getirmektedir (Bang, 2003: 9). İşte bu bakış açısı 'Sivil Yönetişim' olarak adlandırılmaktadır.

Çünkü yönetişim kavramı tek özneliğe ve merkeziyetçi anlayışa karşı bir alternatif olarak varlık kazanmıştır. Yönetimde iş bölümünün zorunluluğuna atıfta bulunurken (Tortop vd., 2012: 338) iş bölümünün yalnızca devletin odak noktasında olması gerektiğini düşünmek yanlış bir anlamlandırma olacaktır. 
Sinerjik Devlet: Sinerji Yunanca bir kelime olarak "birlikte çalışmak" anlamına gelmektedir. Bu anlama göre sinerji daima bir işi en az iki ortak ile birlikte yapılmasını kurgulamaktadır (Latash, 2008: 5). Bu kurgunun içerisinde mutlak bir biçimde fazladan değer üretmek mantığı yer almaktadır. Bu mantık parçaların birleştirilmesi sonucunda elde edilen bütünden daha fazla değer kazanmak amacını taşımaktadır. Bu mantığın matematiksel formülasyonu şu şekildedir: "1+1+1=4" veya "1+1=3" (Aktan, 2012: 262). Bir diğer yaklaşım ile sinerji kavramının vurgulamak istediği sonuç kaynak, yetenek ve bakış açısı gibi farklı güçlerin bir araya gelmesi sonucunda olması gereken değerden daha fazla katma değer üretilmesine vurgu yapmaktır (Lasker vd., 2001: 183). Dolayısıyla devletin aşırı merkeziyetçilikten sıyrılarak daha fazla değer üretmesi isteniyorsa yanında özellikle sivil karakter taşıyan katılımcılara yer vermesi gerekmektedir. Bu da devleti 'Sinerjik Devlet' haline dönüştürecektir.

\section{Sonuç}

Merkeziyetçilik uzun süren tartışmalara konu olmuş bir ilkedir. Bu ilkenin yaratmış olduğu olumsuzluklara çözüm önerileri sunulmuş ve birçok öneri adem-i merkeziyetçilik ekseninde toplanmıştır. Bu bir açıdan doğru bir yaklaşımı yansıtmakla birlikte, bütün çözümün yalnızca yerele değer vermek, yerelleşmek ve yerelden yönetilmek ile çözümlenebileceği düşüncesi bir ayağı eksik masa gibi sallantıda durmaktadır. Yerelleşirken merkezi unutmak son derece yanlış bir takım sonuçların ortaya çıkmasına sebebiyet verebilecektir. Türkiye'nin üniter yapısını koruyabilmesi için merkeziyetçilik ilkesinin uygulamada kalması gerekmektedir. Bununla birlikte yerelleşme ideali ile merkeziyetçilik uygulamalarında yerel halkın günlük ve yerel nitelik taşıyan ihtiyaçları gibi bazı konular adına yumuşatılmalar yaşanabilmektedir. Dolayısıyla merkeziyetçilik uygulamalarından tamamen vaz geçmek, en azından Türkiye için, pek mümkün görünmemektedir. Ancak merkeziyetçilik uygulamalarının yaratmış olduğu sorunlara da çözüm önerileri sunmak gerekmektedir. Bu çalışmanın ruhunda da bu sorgulamanın ayak izlerine rastlanılmaktadır.

Bu çalışma altında kurgulanmaya çalışılan sonuç devletin, özellikle sivil toplumu yönetime dahil etmesiyle, yeni bir sinerji akımını yaratmasıdır. Bu kurgu kapsamında devlet tek bir çatı altından katı kurallar eşliğinde ve merkezi bir biçimde yönetilmeyecektir. Ancak bu kurgu üniter yapıdan başka bir yönetim biçimini de önermemektedir. Önerilen sonuç sinerji anlayışı içerisinde ve üniter yapıyı koruyarak devletin çok aktörlü yönetilebilmesinin kurgusunu yapmaktır. Bu kurgu devletin sivilleştirilmesi, yerel seviyede yönetişim uygulamalarının yaygınlaştırılması, siyasal katılımın bütün çevrelere yayılması, mahalle seviyesinde devlet yönetimine katılımının yollarının aranması ve çok aktörlü yönetim modelinin sivilleştirilmesi ile tamamlanmaya çalışımıştır. Böylece Türkiye Cumhuriyeti'nin üniter yapısı korunarak, merkeziyetçilik ilkesinden vaz geçilmeden ve yerelleşme idealinin de federalizm ekseninde evrimleşmesine izin verilmeden çözüm önerileri üretilmiştir. Bu noktada merkeziyetçilik ilkesi ile yönetimin alt seviyeye indirgenmesinin bir çelişki olduğu düşünülebilir, ancak önerilen çözümsel ve eyleme yönelik kurgu bu hedefe nasıl ulaşılacağının rotasını çizmektedir. Önerilen çözümsel modeller ile Türkiye Cumhuriyeti devleti sivil, katılımcı, çok aktörlü, üniter ve merkeziyetçi bir devlet olarak varlığını devam ettirecektir. 


\section{Kaynaklar}

Adıgüzel, Şenol (2003), "Yerel Düzeyde Yönetime Katılım ve Yerel Yönetim Sürecindeki İşlevleri Açısından "Yerel Gündem 21": Malatya Belediyesi Yerel Gündem 21 Örneği", Çağdaş Yerel Yönetimler Dergisi, C. 12, S. 1: 45-63.

Aktan, Coşkun Can (2012), "Sinerjik Yönetim: Organizasyonlarda Sinerji Etkisi”, Organizasyon ve Yönetim Bilimleri Dergisi, 4 (1): 260-280.

Aktan, Coşkun Can (2003), Değişim Çağında Devlet, 1. Baskı, Konya: Çizgi Kitabevi.

Alada, Adalet Bayramoğlu (2008), "Kentsel Yönetime Katılımda Mahalle", DOSYA-08: Yerel Yönetimlere Katılım, Bülten 64, Aralık, Mimarlar Odası Ankara Şubesi Yayını, 1-11.

Alkan, Haluk (2000), "Karar Alma Süreçlerine Katılım Sistemleri Açısından Türkiye Ekonomik ve Sosyal Konseyi”, Amme idaresi Dergisi, 33 (2): 57-77.

Ataay, Faruk (2006), Türkiye'de Yönetim ve "Sivil Toplum" Tartışmaları Üzerine Bir Değerlendirme, MEMLEKET Siyaset Yönetim Dergisi, S. 1: 121-141.

Aydın, Ahmet Hamdi (2009), Türk Kamu Yönetimi Sistemi-Niteliği-Örgütü-Sorunları, Güncelleştirilmiş 3. Baskı, Ankara: Seçkin Yayıncılık.

Bang, Henrik P. (2003), "Governance As Political Communication”, Governance As Social and Political Communication, (Edited By Henrik P. Bang), Manchester University Press, Manchester and New York: 7-23.

Bilgiç, Veysel K. ve Serdar Kenan Gül (2009), "Türkiye'de Yerelleşme Politikaları”, VII. Kamu Yönetimi Forumu: Küreselleşme Karşısında Kamu Yönetimi Bildiriler Kitabı, s. 612-626, Kahramanmaraş Sütçü İmam Üniversitesi İktisadi ve Idari Bilimler Fakültesi (8-10 Ekim 2009), Kahramanmaraş.

Çaha, Ömer (2012), Aşkın Devletten Sivil Topluma, Beşinci Baskı, Ankara: Orion Kitabevi.

Çevik, Hasan Hüseyin (2012), Kamu Yönetimi Kavramlar - Sorunlar - Tartışmalar, Gözden Geçirilmiş 2. Baskı, Ankara: Seçkin Yayıncılık.

Çukurçayır, Mehmet Akif (2013), Yerel Yönetimler Kuram, Kurum ve Yeni Yaklaşımlar, 2. Baskı, Konya: Çizgi Kitabevi.

Çukurçayır, Mehmet Akif (2012), Siyasal Katılma ve Yerel Demokrasi, 4. Baskı, Konya: Çizgi Kitabevi.

Demir, Konur Alp ve Hikmet Yavaş (2015), “Kamu Yönetiminin Geleceği Üzerine Kavramsal Bir Tartışma”, Yönetim Bilimleri Dergisi, 13 (25): 91-113.

Demir, Konur Alp (2014a), “Merkeziyetçi Yönetim Kıskacında Sivil Toplum Çıkmazı”, Dumlupınar Üniversitesi Sosyal Bilimler Dergisi, S. 41: 61-70.

Demir, Konur Alp (2014b), "Klasik Kamu Yönetimi Yapısından Yerelleşmeye Geçiş: Yönetişim Kapsamında Bir Değerlendirme", Muş Alparslan Üniversitesi Sosyal Bilimler Dergisi, C. 2, S. 2: 151-171.

Demir, Fevzi, Zeynel Bakıcı ve Serkan Çınarlı (2011), Etkin Demokratik Hukuk Devleti, Ankara: Orion Kitabevi.

Dursun, Davut (2012), Siyaset Bilimi, Gözden Geçirilmiş 6. Baskı, İstanbul: Beta Yayınevi.

Emrealp, Sadun (2010), Türkiye'nin Katılımcı-Demokratik Yerel Yönetişim Modeli Olarak Dünyaya Armağanı, Kent Konseyleri, 2. Baskı, İstanbul: UCLG-MEWA Yayını.

Erdagöz, Özcan (2012), “Mahalle Yönetimi ve Geleceği”, Uyuşmazlık Mahkemesi Dergisi, S. 1: 59-101.

Eryılmaz, Bilal (2012). Kamu Yönetimi Düşünceler - Yapılar - Fonksiyonlar - Politikalar, Genişletilmiş ve Gözden Geçirilmiş 5. Baskı, Kocaeli: Umuttepe Yayınları.

Göküş, Mehmet, Erdal Bayrakcı ve Hakan Alptürker (2013), “Mahalle Yönetimi ve Mahalle Muhtarlarının Vatandaşlar Tarafından Değerlendirilmesi", Süleyman Demirel Üniversitesi Iktisadi ve Idari Bilimler Fakültesi Dergisi, C. 18, S. 2: 31-45.

Gül, Hüseyin, Hakan Mehmet Kiriş, Nilüfer Negiz ve İsmail Gökdayı (2014), Türkiye'de Yerel Yönetimler ve Yerel Siyaset, Ankara: Detay Yayıncılık.

Güler, Birgül Ayman (2000), “Yerel Yönetimleri Güçlendirmek mi? Ademi Merkeziyetçilik mi?”, Çağdaş Yerel Yönetimler Dergisi, C. 9, S. 2: 14-29.

Kapani, Munci (2010), Politika Bilimine Giriş, Ankara: Bilgi Yayınevi.

Karaçor, Süleyman (2009), "Yeni İletişim Teknolojileri, Siyasal Katılım, Demokrasi”, Celal Bayar Üniversitesi Iktisadi ve Idari Bilimler Fakültesi Yönetim ve Ekonomi Dergisi, C. 16, S. 2: 121-131.

Karar Alma Sürecine Sivil Katılım İçin İyi Uygulama İlkesi, (Karar Alma Sürecine Sivil Katılım İçin Uluslararası Belgeler), (Uluslararası Sivil Toplum Kuruluşları Konferansı'nın 1 Ekim 2009 tarihli Toplantısında Kabul Edilen Belge), 


\section{Eskişehir Osmangazi Üniversitesi IïBF Dergisi}

http://www.tkmm.net/dosya/ocg/tbmm-ortak/paris-ilkeleri-ve-ingo.pdf, (Erişim Tarihi: 14.12.2017).

Keleş, Ruşen (1995), “Hizmette Halka Yakınlık (Subsidiarity) Ilkesi ve Yerel Yönetimler”, Çağdaş Yerel Yönetimler Dergisi, C. 4, S. 1: 3-14.

Kıvanç, Osman (2011), "Karar Alma Sürecine Sivil Katılım İçin İyi Uygulama İlkesi”, Idarecinin Sesi Dergisi, S. Kasım-Aralık: 20-25.

Lasker, Roz D. Elisa S. Weiss \& Rebecca Miller (2001), “Partnership Synergy: A Practical Framework for Studying and Strengthening the Collaborative Advantage", The Milbank Quarterly, C. 79, S. 2: 179-205.

Latash, Mark L. (2008), Synergy, New York: Oxford University Press.

Löeffler, Elke, Sinan Özden ve Sezin Üskent (2012), Vatandaş Katılımını Arttırma Rehberi, Türkiye Yerel Yönetim Reformu Uygulamasının Devamına Destek Projesi (LAR Aşama II), http://www.migm.gov.tr/kurumlar/migm.gov.tr/YAYINLAR/REHBERLER/Katilim\%20Rehberi_09.01.2012.pdf, http://www.migm.gov.tr/yayinlar, (Erişim Tarihi: 09.12.2017).

Ökmen, Mustafa ve Bekir Parlak (2008), Kuramdan Uygulamaya Yerel Yönetimler ilkeler Yaklaşımlar ve Mevzuat, Bursa: Alfa Aktüel Yayınevi.

Önder, Özgür (2013), "Yerelleşme Ve Yerel Demokrasinin Güçlendirilmesi Bağlamında Yerel Katılım”, Uluslararası Yönetim iktisat ve işletme Dergisi, C. 9,S. 18: 311-326.

Özgişi, Tunca (2014), "Türkiye'de Toplumsal Değişimin Siyasi Katılıma Etkisi”, Tesam Akademi Dergisi, C. 1, S. 1: 52-101.

Pabst, Adrian (2012), "The Civil State: An Alternative Model of Democracy and Modernization”, In: Inozemtsev, Vladislav and Dutkiewicz, Piotr, eds. Democracy versus Modernization: A Dilemma for Russia and for the World. BASEES/Routledge Series on Russian and East European Studies. London: Routledge: 179-198.

Parlak, Bekir ve Zahid Sobacı (2012), Ulusal ve Küresel Perspektifte Kamu Yönetimi Teorik ve Pratik, Gözden Geçirilmiş ve Geliştirilmiş 4. Baskı, Bursa: MKM Yayıncılık.

Polatoğlu, Aykut (2003), Kamu Yönetimi Genel ilkeler ve Türkiye Uygulaması, Genişletilmiş 2. Baskı, Ankara: ODTÜ Yayıncılık (METU Press).

Şahin, Musa ve Esra Işık (2011), “Osmanlı'dan Cumhuriyete Mahalle Yönetimi”, Dumlupınar Üniversitesi Sosyal Bilimler Dergisi, S. 30: 221-230.

Toprak, Zerrin (2015), "Türkiye'de Yerel Yönetimler-Yapılanma Merkez -Yerel Yönetim illişkileri", http://kisi.deu.edu.tr//zerrin.toprak/TURKIYE'DE\%20YEREL\%2OYONETIMLER\%20YAPILANMA.pdf, (Erişim Tarihi: 05.12.2017).

Toprak, Zerrin (2006), Yerel Yönetimler, 6. Baskı, Ankara: Nobel Yayın Dağıtım.

Uysal, Birkân (1984), "Siyasal Katılma ve Katılma Davranışı Üzerinde Ailenin Etkisi”, Amme İdaresi Dergisi, C. 17, S. 4: 109-134.

Vögele, Michael (2007), "Türkiye'de Sivil Toplum Diyaloğu: Michael Vögele ile Röportaj”, AB Türkiye Görünüm (Avrupa Komisyonu Türkiye Delegasyonu'nun Periyodik Yayını), S. 9: 8-9.

Yaman, Murat (2015), “AB ve Yerel Yönetimler”, Yerel Yönetimler, (Editör: Kemal Görmez), Ankara: Orion Kitabevi: 247270.

YASADER (Yasama Derneği) (2008), "Karar Alma Sürecine Yurttaş Katılımı ve Sivil Diyalog”, Ekim, NDI (National Democratic Institute) Türkiye.

http://www.yasader.org/web/yasama_surecine_katilim/1/KararAlma.pdf, (Erişim Tarihi: 11.12.2017).

Yaylı, Hasan ve Gülçin Eroğlu (2015), "Yerel Katılım Bağlamında Türkiye'de Kadın Temsili”, International Journal of Science Culture and Sport (IntJSCS), C. 11, S. 3: 504-524.

Yetiş, Mehmet (2006), "Tocqueville ve Merkeziyetçilik Sorunu", Ankara Üniversitesi Siyasal Bilgiler Fakültesi Dergisi, C. 61, S. 3: 279-308. 